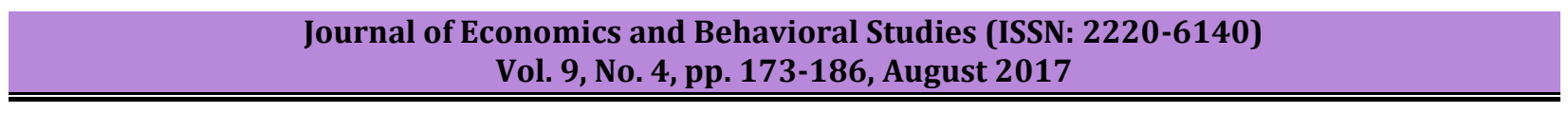

\title{
Does Competition Cause Stability in Banks? SFA and GMM Application to Sub-Saharan Africa Commercial Banks
}

\author{
Joseph Olorunfemi Akande, Farai Kwenda \\ University of KwaZulu-Natal, Durban, South Africa \\ akandeo.joseph@gmail.com, kwendaf@ukzn.ac.za
}

\begin{abstract}
Investigating the competition-stability view in relation to the banking sector, the intention behind this study was to find out how far efficiency is associated with a competitive banking environment and if it warrants the continued agitation towards fostering increased competition in banking markets around the world. This view has significant support in spite of the potential instability that could possibly result from risk appetite, which the competition-fragility view holds to be associated with competition. We employed a stochastic frontier analysis (SFA) to model an instrumental variable of competition resulting from increased efficiency or inefficiency due to bank-level competition, which we used in the regression of competition against stability using the generalized method of moments (GMM). We found that competition increased the efficiency of the banking sector over the study period. The regression results of our instrument against stability in the Sub-Saharan Africa region was found to be positive and strongly significant with stability providing evidence of transmission from competition to efficiency to stability, and, hence consistent with competition-stability views. Our conclusion is that while competition is desirable, it must be optimized to enhance efficiency without which the effects become detrimental. Therefore, there must be ongoing regulation to check excessive competition.
\end{abstract}

Keywords: Competition, Stability, Efficiency, Stochastic Frontier Analysis, Commercial Banks

\section{Introduction}

Competition and stability in banks are important issues to bankers and regulators alike especially in the wake of the 2007/2009 financial crisis. Bank competition has become even more of concern as policy makers in the Sub-Saharan Africa (SSA) region rethink their strategies to break the yoke of poverty and transform their economies to those of their developed counterparts. Policy expectation is that a competitive banking environment will promote efficiency, increase overall competitiveness in other sectors of an economy, and thus promote economic growth. However, the competition-stability trade-off means that caution must be applied in order not to sacrifice financial system stability in the bid to engender competition to stimulate economic growth. In this study, the role of competition in the financial stability of the SSA region is examined by evaluating a panel data analysis of 37 SSA countries' commercial banks' data. Over the years, the findings of both theoretical and empirical papers on the relationship between competition and stability have been mixed, indefinite and inconclusive. Yet, a new look at the role of bank competition in bringing about the dynamic efficiency of the banking system and other sectors without compromising financial stability is now essential if the SSA region is to harness the gains of competition without compromising financial system stability.

There is an ongoing debate on the effect of competition on stability. Two strands of literature exist, one for and one against the competition-stability view (Agoraki, Delis \& Pasiouras, 2011; Schaeck \& Cihák, 2014). Specifically in Africa, there have been two conflicting views. Moyo, Nandwa, Council, Oduor, and Simpasa (2014) found evidence to support competition-stability views while Kouki and Al-Nasser (2014) posit otherwise. According to Casu, Girardone, and Molyneux (2012), these inconsistent results regarding the relationship between competition and stability make interpretation and policy measures very difficult given the economic implications of banking system failure. These authors failed to account for the role of efficiency in the competition and stability relationship, which was identified by Léon (2015) as a gap in the literature especially in Africa. Hence, there is the need for further research to substantiate these views by including the possible transmission channels of competition through efficiency to stability. Therefore, the compelling question is, "does competition cause the stability of banks in the SSA region commercial banks?" This question becomes germane because the SSA region seeks a competitive banking sector in order to stimulate economic growth in the region(Watkins, 2014). 
This paper aligns with a long history of literature dealing with banking competition and, specifically, the concerns as to through what channel of transmission competition impacts on the stability of the system. Our contribution involves the use of a unique method, using stochastic frontier analysis (SFA), to exogenously model an instrumental variable for competition in a regression with stability, and hence fill the gap relating to the transmission mechanism between competition and stability as well as the measurement of how much efficiency is associated with competition. Furthermore, our study provides an extension of the study by Moyo et al. (2014) ${ }^{1}$ to include quite a sizeable number of SSA countries for possible generalization. Our results indicate that the Lerner index is negatively related to stability. However, our instrument of competition provides evidence to support the competition-stability view as held by (Moyo et al., 2014)given that the results of the SFA reveal an increase in efficiency in the competition-efficiency relationship. Therefore, we establish a possible transmission from competition to stability through efficiency in the banking sector of the SSA region, implying that banking competition is not bad after all, but has to be optimized. The rest of the paper is organized as follows. Section 2 reviews the literature that deals with competition, efficiency and stability relationships. Section 3 presents our methodology, and in section 4 we present the empirical results. Section 5 concludes.

\section{Literature Review}

The place of competition in banking has been a subject of intense controversy among practitioners and academics alike. According to Casu (2015), a healthy degree of rivalry is considered necessary for the efficiency of the banking industry and for the stability of the system as a whole. The contestable market theory posits that with free entry and costless exit, market structure will not matter as potential competition guarantees efficient production and pricing regardless of existing players in the market. This, according to Dietsch (1993), brings the market to stability and equilibrium irrespective of the existing market structure. Works that have investigated the nexus between competition and stability have alluded to the presence of efficiency as imperative in any study of the competition and stability relationship (Bolt \& Humphrey, 2010; Castellanos, Del Ángel \& Garza-García, 2016; Genetay, Lin, Molyneux, \& Fu, 2015; Hussain \& Hassan, 2012; Schaeck \& Cihák, 2014). Whether competition results in efficiency, however, is the major preoccupation of the structure conduct performance (SCP) hypothesis? Proponents of this model argue that collusion is anticompetition and causes abnormal profit. Existing literature on this model in Africa tends to find consistency with it (see(Chirwa, 2003; Mugume, 2007), but suffers from the setback of using concentration as a measure of competition. Attempts to overcome the setback of the structural model gave rise to the Lerner index and the Panzar-RosseH-statistics among other non-structural models of measuring competition. In spite of their own various shortcomings, such models offer better competition measures (Muneer et al., 2011; Liu, Molyneux, \& Wilson, 2013).

A simple measure of a firm's efficiency is defined by Farrell (1957)who argues that technical efficiency reflects a firm's ability to obtain maximal output from a given set of inputs. Farrell explains his idea by assuming that firms use two inputs $\left(X_{1}\right.$ and $\left.X_{2}\right)$ to produce one output $(y)$, and production is under the assumption of constant returns to scale. In other words, an increase (decrease) in the inputs leads to the same proportional increase (decrease) of the output. Overtime, the parametric stochastic frontier analysis (SFA) introduced by Farrell (1957) has been used to test this theory empirically. It is important to note that most studies that have considered output-related technical efficiency measures have mainly used pretax income (PTI), return on assets (ROA), and return on equity (ROE), and have concluded that a statistically significant positive relationship exists between competition and efficiency. Banking stability is often measured by systemic banking stress, which is defined as periods when the banking system is unable to fulfill its obligations as they fall due, which the works of Demirguc-Kunt and Detragiache (1997)and Valencia and Laeven (2012) describe as an occurrence of banking crisis. Rather than focusing on systematic banking stress, lots of banking research articles employ bank-level data to compute banking distress. The most popular among these is the Z-score, which sums up the capital-asset ratio and return on assets, weighted by the standard deviation on return on assets (Roy, 1952). Other researchers have also captured the risk of defaults related to the banking loan portfolio using the non-performing loan (NPLs) ratio (Amidu, 2013).

1They considered 16 SSA countries. 
Subsisting empirical models in banking literature, specifically relating to competition-stability and competition-fragility views, reveal that competition could be good or bad for the banking industry as it may result in either stability or fragility. According to the stability view, efficiency comes with competition, which results in systemic stability (Boyd, De Nicoló, \& Jalal, 2009; Schaeck \& Cihák, 2014; Uhde \& Heimeshoff, 2009). The rationale is that competition can have a stabilizing effect on a banking system as efficiency is improved and loan interest rates are lowered, thereby reducing the likelihood of borrower defaults. However, the fragility view holds that competition is associated with moral hazard, adverse selection and agency problems as managers strive to cope with a competitive environment resulting in instability (Agoraki et al., 2011; Ariss, 2010; Beck, De Jonghe, \& Schepens, 2013; Fu, Lin, \& Molyneux, 2014; Yeyati \& Micco, 2007). In line with this view, the explanation is that banks under high competitive pressure choose more excessive risk, thus increasing fragility, which may result in individual bank failure. This means that moral hazard and adverse selection problems are associated with excessive competition in banks where the wrong client is attracted, which in turn pushes up loan rates to the detriment of low-risk customers. Meanwhile, Berger, Klapper, and Turk-Ariss (2009) and Tabak, Fazio, and Cajueiro (2012) found a rather non-linear relationship between competition and stability. As a matter of fact, only one paper has investigated the competitionstability nexus in Africa, thereby providing support for the competition-stability view (Khan et al., 2013; Moyo et al., 2014). In their study of the banking sectors in 16 SSA countries, they found that countries with a higher level of H-statistics, that is, more competitive banking systems, have banks that are more stable. It is imperative that further research is done to revalidate this result and perhaps explore the channels through which competition affects stability in the SSA region and elsewhere. These aspects are among the focus of this study.

Theoretically, banking competition should result in efficiency, hence, the stability of the banking system. However, empirical models and evidence reveal that competition results in both stability and instability. But these models and evidence fail to consider the mediating role of efficiency in the study of the relationship between competition and stability, which probably is the flash point of the endogeneity between them. This study, therefore, fills the gap in the literature on this subject matter by applying stochastic frontier analysis (SFA) to investigate the role of efficiency in the competition-stability relationship. The study also sheds light on how much efficiency is orchestrated that warrants the need for competition, which the competition fragility view argues increases the risk appetite of banks. Hence, the endogeneity issues between competition and stability can also be addressed with the exogenous instrument of competition, which is created to be used in a regression of competition on stability (Suwandi et al., 2016).

\section{Methodology}

The main objective of this work is to investigate the effects of competition on stability among SSA commercial banks. The stochastic frontier analysis (SFA) approach is employed to generate an instrumental variable of competition to be regressed on bank stability for the period 2006 to 2015. Previous studies on the competition and stability view found competition-stability, competition-fragility and a U-shaped relationship (Fu et al., 2014; Schaeck \& Cihák, 2014; Tabak et al., 2012). It has also been established that efficiency is pivotal in the competition and stability relationship (Ariss, 2010; Chirwa, 2003; Mugume, 2007). Yet, as far as we know, no existing studies have explicitly attempted to explore factoring in efficiency in studying the relationship between competition and stability. How is competition related to banks' overall stability? Does competition help to improve or lower banks' efficiency? Answers to these questions will help to establish the role of competition in stability management in banks. Extant literature, however, confronts an inherent problem in regressing competition against stability in order to measure the effects of competition on stability because of the obvious endogeneity problem. Hence, this study follows Chiou and Porter (2015) to develop an exogenous instrument of competition in a regression with stability using the unique SFA.

Concerning the techniques, two methods are used in the literature, these being: the parametric-like SFA (Hughes, Mester, \& Moon, 2001; Hughes, 2013; Hughes, Lang, Mester, Moon, \& Pagano, 2003; Nguyen, 2010)and non-parametric methods such as data envelopment analysis (DEA) (Bauer, Berger, Ferrier, \& Humphrey, 1998; Berger \& Hannan, 1998; Kouki \& Al-Nasser, 2014) among others. SFA is an economic modeling method that was introduced by Jondrow, Lovell, Materov, and Schmidt (1982) following the stochastic production frontier previously introduced by Aigner, Lovell, and Schmidt (1977), Meeusen and Van 
den Broeck (1977) and Farrell (1957). This study adopts the SFA approach because among the modern and most popular frontier analysis techniques, SFA allows the construction of a unique instrumental variable of competition that is exogenous to banks' stability. This approach helps to deal with the endogeneity between competition and stability by using SFA to estimate the inefficiency in our sample of SSA banking sectors. Furthermore, the SFA fits best in analyzing firms' efficiency as it accounts for statistical noise (Coelli, Rao, O'Donnell, \& Battese, 2005; Kao \& Liu, 2009). The argument is that empirical efficiencies calculated from anon-parametric technique such as DEA provide low consistent estimators of the true inefficiencies.

Model Specification: We follow Kouki and Al-Nasser (2014) to estimate bank-level competition of the SSA region commercial banks based on the Lerner index, while the instrument of competition is a developed competition-efficiency hypothesis following Chiou and Porter (2015). The models are discussed going forward.

Lerner Index: Given that the optimal output, $Q T Y_{i}$, of banks $i$, where $i=1 ; N$ at time $t$, is at the point where marginal cost, $M C_{i}$, equals its marginal revenue, $M R_{i}$, the proportion of the difference between the price, $\mathrm{P}_{\mathrm{i}}$, and the marginal cost, $M C_{i}$, on price is the Lerner index denoted as $L I_{i}$ and expressed algebraically as shown in equation (A.1), see (Flamini, Schumacher, \& McDonald, 2009).

$$
L I_{i}=\frac{P_{i}-M C_{i}}{P_{i}}
$$

Where $P_{i}$ is the estimate of average price of bank production in country $i$, which is proxied by the ratio of bank total revenue to total assets (Berg \& Kim, 1994; Berger et al., 2009; Carbó, Humphrey, Maudos, \& Molyneux, 2009; Fernandez de Guevara, Maudos, \& Perez, 2005; Shaffer, 2004). To estimate $M C_{i}$, the first derivative of translog cost function ${ }^{2}$ with respect to $Q T Y_{i}$ is computed. We modelled the translog cost function from the generalised translog production function ${ }^{3}$ through the second-order Taylor series expansion of banks cost in natural logarithm. Relying on the intermediation approach for measuring bank output (Ajisafe \& Akinlo, 2013; Sealey \& Lindley, 1977),the total cost of banks consists of one output,QTY, and three inputs, $W_{1}, W_{2}$, and $W_{3}$, representing price of labour (ratio of personnel expense to total assets), price of physical capital (non-interest expense to fixed assets), and price of fund (interest expense to total deposits), respectively. Hence, we arrived at the reduced translog cost function in panel form in equation (2) below;

$$
\begin{aligned}
& \ln \left(\mathrm{C}_{\mathrm{it}}\right)=\beta_{0}+\beta_{1} \ln \left(\mathrm{QTY}_{\mathrm{it}}\right)+\frac{1}{2} \beta_{2} \ln \left(\mathrm{QTY} \mathrm{it}_{\mathrm{it}}^{2}\right)+\sum_{\mathrm{k}=1}^{3} \theta_{\mathrm{k}} \ln \left(\mathrm{W}_{\mathrm{kit}}\right)+\quad \sum_{\mathrm{k}=1}^{3} \oint_{\mathrm{k}} \ln \left(\mathrm{QTY} \mathrm{it}_{\mathrm{it}}\right) \ln \left(\mathrm{W}_{\mathrm{kit}}\right)+ \\
& 12 \mathrm{k}=13 \mathrm{j}=13 \varnothing \mathrm{kj} \ln (\mathrm{Wkit}) \ln (\mathrm{Wjit})+\mu \mathrm{it}
\end{aligned}
$$

where $Q T Y_{i t}$ is bank output measured as the natural log of total assets of bank $i$ in time $t$ (de Guevara \& Maudos, 2011), $W_{k i t}$ is the vector of the three input prices and $\mu_{i t}$ is the error term. Taking the first derivative of the translog cost function with respect to output the marginal cost is given as:

$$
\mathrm{MC}_{\mathrm{it}}=\frac{\delta \mathrm{C}_{\mathrm{it}}}{\delta \mathrm{QTY}}=\frac{1}{\mathrm{QTT}}\left(\beta_{1}+\beta_{2} \operatorname{In}\left(\mathrm{QTY}_{\mathrm{it}}\right)+\sum_{\mathrm{k}=1}^{3} \oint_{\mathrm{k}} \operatorname{In}\left(\mathrm{W}_{\mathrm{kit}}\right)\right)
$$

Substituting equation(3) for marginal cost in equation (1), the degree of competition will be computed using:

$$
L I=\frac{P_{i t}-\frac{1}{Q T Y}\left(\beta_{i t}+\beta_{2} \operatorname{In}\left(Q T Y_{i t}\right)+\sum_{k=1}^{3} \oint_{k} \operatorname{In}\left(\mathrm{W}_{\text {kit }}\right)\right)}{P_{\text {it }}}
$$

Instrumental Variable of Competition: To construct the instrumental variable of competition, this study follows Chiou and Porter (2015). The inefficiency of the banks is defined by the distance between the specific bank's pretax income and the frontier. Expressing the frontier according to a specific production model, in

\footnotetext{
${ }^{2}$ Another way to estimate cost function is the average variable cost expressed as the ratio of total variable cost to total asset or total income. Although this seems a simpler and straightforward approach, it has been argued to be inaccurate.

${ }^{3}$ Some other common production functional forms include linear, Cobb-Douglas, quadratic, normalised quadratic, constant elasticity of substitution and generalised Leontief functions.
} 
this case, it is assumed that a bank's profitability can be specified as the Cobb-Douglas production function:

$$
\operatorname{In}\left(P B T_{i t}\right)=\alpha+\sum_{h=1}^{H} b_{h} \operatorname{In}\left(X_{i t, h}\right)+v_{i t}-u_{i t}
$$

Where, $v_{i t}$ represents the noise component, considered as a two-sided normally distributed variable and $u_{i}$ equals the non-negative technical inefficiency component. Because $v_{i}$ and $u_{i}$ constitute a compound error term with a specific distribution to be determined, SFA is therefore often referred to as the composed error model.

The SFA in equation (5) is employed to create a unique instrumental variable of bank competition to be used in the regression of competition and stability in the SSA region commercial banks. This should provide answers to the question of, how efficient is a bank in converting the resources with which it has to work into profit in the face of competition? Hence, we develop an unrestricted frontier that determines the highest possible profitability based solely on the employed banks' assets book value. This is specified as:

$$
P B T_{i t}(A B V)=\alpha+b_{1} A B V_{i t}+b_{2}\left(A B V_{i t}\right)^{2}+e_{i t}
$$

Where $P B T_{i t}$ equals pre-tax income, $A B V_{i t}$ is assets book value, $e_{i t}=\oint_{i t}-\lambda_{i t}$, the composite error, $\oint \sim \operatorname{iidN}\left(0, \delta_{\phi}^{2}\right)$, is the stochastic noise, which is a two sided error term, $\lambda \sim \operatorname{iidN}\left(0, \delta_{\lambda}^{2}\right)$, the systematic fall (technical inefficiency) a one-sided error and $\lambda . .0$. The quadratic equation allows for a non-linear relation between the pre-tax income and the book value of asset. The essence is to allow technical efficiency to vary through time, and across the cross-section of banks (Kumbhakar \& Lovell, 2003).

The efficiency scores are estimated using Frontier version 4.1 (Coelli, 1996), a computer programme based on stochastic production functions (Battese \& Coelli, 1992; Battese \& Coelli, 1995)written to provide maximum likelihood estimates of different types of stochastic frontier production as independently introduced by Aigner et al. (1977) and Meeusen and Van den Broeck (1977). It accounts for a truncated normal assumption including panel data with time varying efficiencies, and is hence applicable to our unbalanced panel model, with firm effects having truncated normal random variables distribution assumptions that are allowed to vary systematically with time (Battese \& Coelli, 1992). Next, we develop the second frontier based on the level of banking sector competition. The essence of the unrestricted model is to measure the unconditional inefficiencies of the banks. By restricting the model now, will enable us to develop a measure of incremental efficiency or inefficiency of a banking organisation due to the level of competition within the banking industry. It is this incremental efficiency/inefficiency arising from bank-level competition that the study proposes to use as an instrument for competition in the regression of bank stability on competition.

The restricted model again, in a quadratic form, is as follows:

$$
P B T_{i t}(A B V, B C L)=\alpha+b_{1} A B V_{i t}+b_{2}\left(A B V_{i t}\right)^{2}+b_{3} B C L_{i t}+\varepsilon_{i t}
$$

Where BLC is bank level competition, $\varepsilon_{i t}=v_{i t}-u_{i t}$ is the composite error, such that, $v \sim \operatorname{iidN}\left(0, \delta_{v}^{2}\right)$, is stochastic noise and $u(\geqslant 0) \sim \operatorname{iidN}\left(0, \delta_{u}^{2}\right)$ is the inefficiency orchestrated by the level of competition that the banking sector has to cope with. The estimation of $u$ is the same as in eqn (7) above. Based on the two inefficiencies assessments, the profitability due to the influence of competition can then be measured by subtracting the inefficiency of the unrestricted model from the restricted model thus:

$$
\vartheta_{i t}=u_{i t}-\lambda_{i t}
$$

This, therefore, constitutes the instrumental variable for competition.

From the forgoing, the relationship between the variable specifying banks' stability and competition is analyzed by the regression equation specified as follows:

$$
Y_{k i t}=C_{k i t}+b_{k i t} \vartheta_{k i t}+\varphi_{k i t} \operatorname{In}\left(A B V_{k i t}\right)+\eta_{k i t}
$$

Where $Y_{k i t}$ measures the stability for bank $i$ in country $k$ at year $t$. $C_{k i t}$ is a constant; $b_{k i t}$ is the coefficient of instrumental variable of competition, $\vartheta_{k i t}$, for $k$ 's regression in year $t ; \varphi_{k i t}$ is the coefficient of the natural logarithm of bank asset book value; and $\eta_{k i t}$ is the error term. The book value of asset helps to control for the impact of size on banks' risk-taking behavior (Gatev, Schuermann, \& Strahan, 2009) 
The SSA banking sector's stability is, for the purpose of this study, defined as the Z-score. The Z-score, according to Roy (1952), is used to measure the overall stability of a bank and has been used in the bank literature (see (Čihák, 2012; Kouki \& Al-Nasser, 2014; Laeven \& Levine, 2009; Lepetit \& Strobel, 2013). It is an indicator of banks' probability of insolvency as it estimates the number of standard deviations that a bank's profit has to fall below its expected value before its equity becomes negative. We implement the regression using the generalized method of moments (GMM) regression. The ordinary least squares (OLS) method could not be used because of the departure from normality of the variable $\vartheta$ due to the combined error terms. Unlike other estimators, GMM is robust and does not require information on the exact distribution of the disturbances. The GMM estimator is known to be consistent, asymptotically normal and efficient in the class of all estimators that do not use any extra information apart from that contained in the moment conditions (Abdelkader \& Mansouri, 2013; Arellano \& Bond, 1991; Athanasoglou, Brissimis, \& Delis, 2008; Campbell, Lo, \& MacKinlay, 1997; Gatev et al., 2009; Hamilton, 1994; Roodman, 2006). It is also efficient for a large number of observations over the relatively short term. In addition, GMM deals with endogeneity in a better way than other methods.

Data: We obtained our data on banks for this study from the Bankscope database by Fitch/IBCA Bureau van Dijk for37 SSA countries' commercial banks' financial profiles for the years 2006 to 2015. A total of 440 banks' data ranging from 190 banks in 2006 to 440 banks in 2015 were consulted. The selection is based on the availability of data from the database. SSA countries' selections exclude those we considered as outliers ${ }^{4}$. Bankscope is considered as the most comprehensive database for banking research. Specific data collected relate to total revenue, total assets, interest and non-interest expense, personnel expense, total asset, and total deposits required for the estimation of bank-level competition as contained in the literature (see (Berger et al., 2009; Kouki \& Al-Nasser, 2014) among others). This study considered Roy (1952) proposition of the Zscore as a proxy for the overall stability of the banking sector. It provides a measure of the distance from insolvency of a given bank by combining a bank's profitability, capitalization and volatility of returns. It also estimates the number of standard deviations that a bank's profits have to fall below before its expected equity becomes negative and, hence, is a holistic measure of the end results of whatever risk a bank may undertake. The Z-score has been used in measuring banking sector stability in the literature (see (Čihák, 2012; Kouki \& Al-Nasser, 2014; Laeven \& Levine, 2009; Lepetit \& Strobel, 2013). Both return on asset and equity capital ratio, which are required for the computation of the Z-score, are collected as part of the annualized data obtained from Bankscope. Other specific data collected include annual data on pre-tax income (Chiou \& Porter, 2015) and asset book value (Barro \& Barro, 1990) employed for the input and output variables for the output-oriented stochastic frontier analysis.

\section{Results}

This section sets out the results of our estimations. Based on the questions we posed to actualize the objective of this study, we tested for these three hypotheses related to our expectation of the relationship between competition and stability in the SSA region: 1 . There is no significant relationship between competition and efficiency; 2. There is no significant relationship between competition and stability; 3 . There is no link between competition and stability that results from efficiency. Our assertions are borne out by the level of development of the commercial banks in the SSA region.

Summary of Statistics: The numbers for banks and statistics for the competition measure, and the Lerner index, over the sample years are reported in Table 1. The means of other descriptive statistics are listed: Zscore, the stability measure; ABV, asset book value; ROA, return on asset; ROE, return on equity and PBT, profit before tax. The Lerner index produced a range of competition measures with varying degrees of market power.

\footnotetext{
4 South Africa, having a highly developed and sophisticated banking system, while others, such as Sudan ravaged by wars, were excluded for data availability and consistency.
} 
Table 1: Summary Statistics

\begin{tabular}{|c|c|c|c|c|c|c|c|c|c|c|}
\hline year & $\mathbf{N}$ & $\begin{array}{l}\text { Lerner } \\
\text { Index } \\
\text { mean }\end{array}$ & SD & $\min$ & $\max$ & zscore & abv & roa & roe & pbt \\
\hline 2006 & 190 & 0.256 & 0.166 & 0.001 & 0.837 & 3.543 & 371505 & 0.020 & 0.191 & 10402 \\
\hline 2007 & 215 & 0.269 & 0.156 & 0.013 & 0.784 & 3.205 & 529336 & 0.018 & 0.196 & 12804 \\
\hline 2008 & 250 & 0.288 & 0.177 & 0.011 & 0.967 & 3.380 & 582588 & 0.020 & 0.180 & 18339 \\
\hline 2009 & 275 & 0.294 & 0.188 & 0.010 & 0.921 & 3.295 & 691492 & 0.014 & 0.148 & 14049 \\
\hline 2010 & 296 & 0.296 & 0.183 & 0.000 & 0.979 & 3.274 & 695667 & 0.010 & 0.132 & 18975 \\
\hline 2011 & 320 & 0.282 & 0.173 & 0.003 & 0.977 & 2.989 & 970764 & 0.012 & 0.123 & 20293 \\
\hline 2012 & 357 & 0.324 & 0.194 & 0.005 & 0.998 & 3.235 & 1060910 & 0.013 & 0.116 & 26529 \\
\hline 2013 & 392 & 0.352 & 0.314 & 0.000 & 0.988 & 3.404 & 1153087 & 0.012 & 0.087 & 27427 \\
\hline 2014 & 430 & 0.332 & 0.185 & 0.000 & 0.996 & 3.624 & 1159650 & 0.011 & 0.076 & 27435 \\
\hline 2015 & 440 & 0.324 & 0.196 & 0.001 & 0.996 & 3.484 & 1111977 & 0.011 & 0.069 & 23320 \\
\hline
\end{tabular}

Authors' computation, 2017

As seen in the table, while some banks have indices that are near zero, other indices are close to 1, given the minimum and the maximum columns. This distribution is expected based on the pockets of concentrations that were reported in some banking literature for the SSA region. However, the closeness of the mean of the Lerner index to the minimum values implies a relatively competitive banking market, which could be described as being monopolistic competition in nature. The mean of the Z-score shows indices that are greater than 1 . The higher the Z-score, the better, as a higher Z-score depicts a stable banking system. While the return on assets seems to be quite low in contrast to those of the return on equity, overall, the mean values provide evidence of a banking system that is performing over the periods under investigation, which corroborates the stability reflected by the z-score. This sketchy behavior shown by the summary statistics tends to point to a model of competition, efficiency and stability, which this study hopes to reveal in subsequent sections of the paper.

Instrumental Variable: Instrumental variable for competition descriptive statistics over the years sampled are displayed. The instrumental variable $\vartheta_{i t}=u_{i t}-\lambda_{i t}$ is a measure of incremental bank inefficiency/efficiency due to bank level competition and/or degree of market power, where the stochastic frontiers are $P B T_{i t}(A B V)=\alpha+b_{1} A B V_{i t}+b_{2}\left(A B V_{i t}\right)^{2}+e_{i t} \quad$ and $P B T_{i t}(A B V, B C L)=\alpha+b_{1} A B V_{i t}+$ $b_{2}\left(A B V_{i t}\right)^{2}+b_{3} B C L_{i t}+\varepsilon_{i t}$. The first frontier measured the level of banks' inefficiencies in converting their resources to output (profit). This determines the maximum possible income achievable from a given level of asset, which is exogenous to a specific bank because it is determined from the data of all banks in the sample. The distance from this frontier to any specific bank's actual income is a measure of a bank's inefficiency. With the second frontier, the instrument of competition is created conditioned to bank-level competition given its production capacity. The incremental inefficiency/efficiency from the second frontier is a function of bank competition; in other words, the difference between the second and the first frontier's efficiency scores is used as the instrument for competition (see Table 2 for the description of our instrumental variable).

Table 2: Instrumental Variable Distribution

\begin{tabular}{lllllll}
\hline year & mean & SD & kurtosis & skewness & min & max \\
\hline 2006 & $-4.08368 \mathrm{E}-06$ & $7.04307 \mathrm{E}-05$ & 66.46838888 & 7.558965536 & $-6.73 \mathrm{E}-05$ & 0.00067622 \\
2007 & $5.52651 \mathrm{E}-07$ & 0.000163903 & 167.7121601 & 12.41309188 & -0.00015733 & 0.00224774 \\
2008 & $-1.35568 \mathrm{E}-05$ & $4.3518 \mathrm{E}-05$ & 31.93930828 & 4.276213275 & -0.00011717 & 0.00036802 \\
2009 & $-4.68567 \mathrm{E}-06$ & 0.000117389 & 127.1648157 & 10.31878458 & -0.0001322 & 0.00157034 \\
2010 & $2.18235 \mathrm{E}-05$ & 0.000305294 & 119.5363149 & 10.46394279 & -0.00013972 & 0.00395189
\end{tabular}




\begin{tabular}{lllllll}
\hline 2011 & $-1.00525 \mathrm{E}-06$ & 0.000216933 & 272.8637947 & 15.94867855 & -0.00015109 & 0.0037175 \\
2012 & $2.69355 \mathrm{E}-05$ & 0.000644388 & 343.9703535 & 18.38833656 & -0.00014222 & 0.01205672 \\
2013 & $-9.40666 \mathrm{E}-06$ & $9.1474 \mathrm{E}-05$ & 56.41178163 & 5.86973908 & -0.00035134 & 0.0010471 \\
2014 & $-3.38535 \mathrm{E}-06$ & 0.000123564 & 62.19802236 & 7.017162991 & -0.00015697 & 0.00133269 \\
2015 & $-1.14878 \mathrm{E}-05$ & $8.35993 \mathrm{E}-05$ & 46.01088163 & 5.639606657 & -0.0001813 & 0.0008062
\end{tabular}

Authors' estimation, 2017

Based on pairwise correlation, the instrument is strongly negatively correlated with the Lerner index and the variable it replaces at 0.7732 with $0.0000 \mathrm{p}$-value, and uncorrelated with the residual at -0.0000 with 1.0000 p-value, affirming that it is a good instrument. We found a marginal efficiency from the results of the SFA, that is, the efficiency scores are closer to the frontier with bank-level competition as against the absence of competition. This provides evidence to support a positive relationship between competition and efficiency. We also found consistency with Castellanos et al. (2016), Çelik, Kaplan, and Şahin (2015) and Casu and Girardone (2009)who argued that banks in a competitive system become more efficient, substantiating the quiet life hypothesis. However, a recent account by Apriadi, Sembel, Santosa, and Firdaus (2016) posits that competition negatively Granger causes efficiency. For our sample, the distribution of $\vartheta$ in the same year tends to be skewed to the right-hand side and has positive excess kurtosis. On this note, we consider a nonparametric and use a normality-free regression model for our analysis to avoid the possible errors of estimation.

GMM Results: The results of our generalized method of moments (GMM) estimations from models 1 - 5 are shown in Table 4. To enhance robustness, we present in Table 3 both pairwise correlation coefficients between the tested variables, the instrumental variable for competition, $\vartheta$, and the Lerner index. We did not test for the presence of cross-sectional dependence in our panel estimation, as according to Chudik, Pesaran, and Tosetti (2011) and Chudik and Pesaran (2013), it is ideal to relax the cross-sectional dependence assumption in large cross-sections like ours. They argue that even where it exists, controlling for it is difficult and the result would not necessary be biased.

Table 3: Correlation Results

\begin{tabular}{lllllllllll}
\hline & $\mathbf{2 0 0 6}$ & $\mathbf{2 0 0 7}$ & $\mathbf{2 0 0 8}$ & $\mathbf{2 0 0 9}$ & $\mathbf{2 0 1 0}$ & $\mathbf{2 0 1 1}$ & $\mathbf{2 0 1 2}$ & $\mathbf{2 0 1 3}$ & $\mathbf{2 0 1 4}$ & $\mathbf{2 0 1 5}$ \\
\hline$\vartheta$ \& z-score & 0.1644 & 0.2468 & -0.027 & 0.0341 & 0.2341 & 0.2791 & 0.2583 & -0.0572 & 0.1089 & 0.0296 \\
p-value & 0.0234 & 0.0003 & 0.6712 & 0.5737 & 0.0000 & 0.0000 & 0.0000 & 0.2584 & 0.0239 & 0.5363 \\
$\begin{array}{l}\text { Lerner index } \\
\text { \& z-score }\end{array}$ & -0.1346 & -0.2072 & -0.0259 & -0.0098 & -0.3066 & -0.3131 & -0.2533 & 0.0038 & -0.0681 & -0.0174 \\
p-value & 0.064 & 0.0023 & 0.6834 & 0.8715 & 0.0000 & 0.0000 & 0.0000 & 0.9409 & 0.1586 & 0.7166 \\
$\begin{array}{l}\text { Lerner } \\
\text { index \& }\end{array}$ & 0.0198 & 0.2863 & 0.0183 & 0.2339 & 0.0131 & -0.0737 & 0.1276 & -0.0045 & -0.0204 & -0.0387 \\
p-value & 0.7859 & 0.0000 & 0.7737 & 0.0001 & 0.8225 & 0.1886 & 0.0159 & 0.9297 & 0.6735 & 0.4184 \\
$\begin{array}{l}\text { Lerner } \\
\text { index \&roa }\end{array}$ & 0.0338 & 0.2649 & 0.0771 & 0.3189 & 0.039 & -0.0596 & 0.1213 & 0.0559 & 0.0715 & 0.0062 \\
p-value & 0.6433 & 0.0001 & 0.2244 & 0.0000 & 0.5041 & 0.288 & 0.0219 & 0.2699 & 0.1389 & 0.8966 \\
$\begin{array}{l}\text { Lerner index } \\
\text { \& roe }\end{array}$ & -0.0005 & 0.0496 & 0.0788 & 0.1581 & 0.0224 & 0.0099 & 0.0358 & 0.0302 & 0.0072 & -0.0118 \\
p-value & 0.9943 & 0.4716 & 0.2184 & 0.0092 & 0.7027 & 0.8609 & 0.5002 & 0.5521 & 0.882 & 0.8057 \\
\end{tabular}

Author's

Estimation 2017 
For efficient and robust estimates, this study uses the dynamic panel data estimation technique, and opted for the two-step system GMM with robust and orthogonal deviation to account for the unbalanced nature of the panel. To control for the size of the banks, the coefficient of $\vartheta$ and those of the Lerner index are generated by GMM regression with a constant and the natural logarithm of the book value of assets. The coefficients of the control variable and the constant term are reported in Table 4.

A cursory look at the results in Table 4 and the stability measure in the models 1 and 2 exhibit a statistically significant and positive relationship with their lagged values, which implies that previous financial systems' stability in the banking sector largely determine the current stability of the system as well as persistence in the relationship. Our variable of interest, $\vartheta$, the instrument of competition, is shown in model $1 . \vartheta$ is the instrument of competition ${ }^{5}$, derived from the relationship between competition and efficiency using SFA. The essence of this instrument is, firstly, to create a variable that is exogenously related to stability in the regression of stability on competition and, secondly, a variable that can capture efficiency in competition. By this means we found a new way to capture the competition and stability relationship whose results have been inconsistent in the literature largely due to the endogeneity between the duo. We found the instrument to be statistically significant and positively related to the Z-score, the stability measure. This offers far-reaching implications for the literature on competition and stability. We found consistency with Petersen and Rajan (1995), Berger and Mester (1997) and Williams (2004), who argued that efficiency enhances the administration and management of banks' assets portfolios that reduces nonperforming loans hence improving the stability of banks. It is, therefore, logical for a competitively efficient banking sector to be financially stable. This finding aligns with the studies of Schaeck and Cihák (2014)where it is argued that efficiency is the conduit pipe through which the effects of competition in the banking system influence stability. Thus, our results establish a transmission mechanism from competition to efficiency to stability in the banking sectors of the SSA region. We therefore infer a direct positive relationship between competition and stability in the SSA region in line with the competition-stability views of(Akins, Li, Ng, \& Rusticus, 2016; Moyo et al., 2014; Schaeck, Cihak, \& Simon, 2009; Soedarmono, Machrouh, \& Tarazi, 2013) among others, and argue against the competition-fragility views of (Agoraki et al., 2011; Kouki \& Al-Nasser, 2014; Maghyereh \& Awartani, 2016), among others.

Table 4: GMM Regression

\begin{tabular}{|c|c|c|c|c|c|}
\hline & $\begin{array}{l}\text { Model } \\
\text { (1) }\end{array}$ & $\begin{array}{l}\text { Model } \\
\text { (2) }\end{array}$ & $\begin{array}{l}\text { Model } \\
\text { (3) }\end{array}$ & $\begin{array}{l}\text { Model } \\
(4)\end{array}$ & $\begin{array}{l}\text { Model } \\
\text { (5) }\end{array}$ \\
\hline \multirow{2}{*}{$\begin{array}{l}\text { Variable } \\
\text { L.zscore }\end{array}$} & z-score & z-score & pbtaratio & roa & roe \\
\hline & $\begin{array}{l}0.785^{* * *} \\
(0.0582)\end{array}$ & $\begin{array}{l}0.580^{* * *} \\
(0.0875)\end{array}$ & & & \\
\hline$\Theta$ & $\begin{array}{l}287.4^{* * *} \\
(-108.5)\end{array}$ & & & & \\
\hline Lnabv & $\begin{array}{l}0.322^{*} \\
(0.187)\end{array}$ & $\begin{array}{l}0.195^{* *} \\
(0.0803)\end{array}$ & $\begin{array}{l}0.00168^{* *} \\
(0.000751)\end{array}$ & $\begin{array}{l}-0.00316^{* *} \\
(0.00139)\end{array}$ & $\begin{array}{l}3.052^{* * *} \\
(0.497)\end{array}$ \\
\hline lerner index & & $\begin{array}{l}-0.0345^{* * *} \\
(0.0084)\end{array}$ & $\begin{array}{l}0.000221^{* * *} \\
(0.0000647)\end{array}$ & $\begin{array}{l}-5.85 \mathrm{e}-05^{* *} \\
(-0.0000254)\end{array}$ & $\begin{array}{l}0.0806^{* *} \\
(0.0386)\end{array}$ \\
\hline L.pbtaratio & & & $\begin{array}{l}0.432^{* * *} \\
(0.0337)\end{array}$ & & \\
\hline L.roa & & & & $\begin{array}{l}0.562^{* * *} \\
(0.132)\end{array}$ & \\
\hline L.roe & & & & & $\begin{array}{l}0.146^{* *} \\
(0.0596)\end{array}$ \\
\hline Constant & $\begin{array}{l}-3.399 \\
(2.455)\end{array}$ & $\begin{array}{l}-1.326 \\
(1.044)\end{array}$ & $\begin{array}{l}-0.00838 \\
(0.01)\end{array}$ & $\begin{array}{l}0.0478^{* * *} \\
(0.017)\end{array}$ & $\begin{array}{l}-25.98^{* * *} \\
(6.331)\end{array}$ \\
\hline $\operatorname{AR}(2)$ & 0.080 & 0.100 & 0.771 & 0.685 & 0.295 \\
\hline Hansen J stats & 0.451 & 0.176 & 0.496 & 0.655 & 0.732 \\
\hline Wald (chi2) & 942.24 & 87.72 & 185.35 & 32.35 & 61.06 \\
\hline
\end{tabular}

${ }^{5} \mathrm{~A}$ proxy for competition 


\begin{tabular}{llllll} 
Prob $>$ chi2 & 0.000 & 0.000 & 0.000 & 0.000 & 0.000 \\
Observations & 2,725 & 2,725 & 2,725 & 2,725 & 2,696 \\
Number of id & 430 & 430 & 430 & 430 & 429 \\
\hline
\end{tabular}

Standard errors in parentheses: ${ }^{* * *} p<0.01,{ }^{* *} p<0.05,{ }^{*} p<0.1$. Where $\vartheta$ represents the instrument and Lerner index in the competition measure, while pbtaratio, roa and roe depict profit before tax to asset book value ratio, return on assets and return on equity, respectively, these being surrogate efficiency measures.

For robustness, the original variable, the Lerner index that is the competition measure is also found to be statistically significant but negatively related to the stability measure. It suggests an inverse relation between competition and stability where competition is not associated with efficiency. This may be the reasons why some models have found competition to be fragile for banking sectors in the literature in some parts of the world, and it provides evidence that if competition is not well managed so as to cause efficiency it may be detrimental to the system, as is argued in the competition-fragility view. We further tested the results of the SFA by using a range of efficiency measures as contained in models 3,4 and 5 for consistencies and comparison. Model 3 measures the relationship between the Lerner index and pretax income to assets ratio (pbtaratio). Pretax income measures the intrinsic profitability of the sampled banks to enable comparability across borders because of differences in corporate taxes. Hence, pbtaratio is an indicator of how profitable a bank is relative to its total assets. It gives an idea as to how efficient management is at using its assets to generate earnings. The study found that the Lerner index is statistically significant and positively related with pbtaratio. That is, a $1 \%$ increase in the competition index will mean a $0.0221 \%$ increase in profitability. This finding confirms the SFA results and existing theories that posit a positive relationship between competition and efficiency. We have thought that the level of development of the SSA region banks will take its toll on the results, as existing models relate largely to developed countries.

The results of the Lerner index and return on assets, however, give a statistically significant but inverse relationship. While roa and pbtaratio measure the same thing, we assume that the difference in the results of roa from those of pbtaratio, is largely due to the impact of tax that banks face, which differ across countries. The SSA region may have to consider tax harmonization, as every sacrifice to achieve sustainable economic growth will be worthwhile. Finally, Model 5 results show a statistically significant and positive relationship between the Lerner index and return on equity (roe). ROE measures a corporation's profitability by revealing how much profit a company generates with the money shareholders have invested. These results are a further affirmation of a positive relationship between competition and efficiency in the SSA region commercial banks. In general, this study found the result of Model 1 to be consistent with the competitionstability views model in the literature (Moyo et al., 2014; Schaeck \& Cihák, 2014), where it is argued that competition brings about efficiency, which then leads to stability of the banking sector. Our results confirm this transmission as shown from the result of SFA that reported a marginal efficiency being associated with competition in the SSA region. The implication will mean that provided competition can be managed to such a level that it produces efficiency, it will continue to enhance stability. It is not surprising, however, that competition on its own is inversely related to the stability measure, which substantiates the fact that competition on its own will more likely be inimical to the banking system, unless it improves efficiency without which it adds no value to the system, but rather causes instability.

The marginal efficiency found in the SFA result is also confirmed in the results of models 3 and 5, which are seen to be consistent with the literature on competition and efficiency (Chirwa, 2003; Kouki \& Al-Nasser, 2014; Mugume, 2007). Notwithstanding that, there seems to exist an inverse relationship between competition and return on asset, and on the average, we tend to find evidence to support the aforementioned assertion that competition does cause efficiency. The results of these models are further supported by the tests of overall significance through the Wald test (see Table 4). This test shows that the estimated results for the five models are statistically significant. Therefore, all the variables used as determinants are all desirable and would influence both stability and efficiencies of the banking sectors significantly. We also did not find any violation of serial correlation and over-identification of instruments as the results of the test show the respective thresholds were satisfied(see (Mileva, 2007; Roodman, 2006). 


\section{Conclusion}

In the course of this paper, we have set out to investigate the relationship between competition and stability especially as it relates to the SSA banking sector. To achieve this, we leveraged the relationship between competition and efficiency as contained in the literature to craft a new way of rethinking this relationship by developing an instrument for competition using SFA. We then used this instrument in a regression of competition against stability. We used the Z-score as a surrogate for stability. The Z-score measures the overall stability of the banking system. Our competition measure is the Lerner index, which enables us to estimate the market power of the 440 banks in our sample over the study period. The result of our bank-level competition with the Lerner index suggests a monopolistically competitive SSA banking system. The efficiency scores generated from the SFA reveal an actual sense that efficiency increases with competition in the SSA banking system over the period under consideration. This provides consistency with literatures that argue that efficiency is inherent in competition; hence, we conclude that competition is good for the banking system as it engenders the dynamic efficiency of the system.

Using GMM, we found the coefficient of our instrument to be strictly positive and statistically significant with our stability measure. This affirms a possible transmission from competition to efficiency and then to stability. Hence, this is consistent with the competition-stability view, which argues that competition brings about efficiency, which then causes stability. We, therefore, conclude that competition causes stability in the SSA region banking sector. However, as a rider, efforts must be made to manage competition such that efficiency is ensured, because regressing the Lerner index against stability shows a negative and statistically significant relationship. Again, this is not surprising in that competition fragility has already been reported in the literature, thus, the key is managing competition for efficiency. Our contribution lies in accounting for the role of efficiency in the competition-stability relationship without which competition may be undesirable for the banking system. We also substantiated the subsisting competition-stability view study in Africa to safe the cost to policy making of conflicting views in crafting policies on competition and stability relationship. This result presupposes that driving and maintaining sustainable banking competition in the SSA region is fundamental and a welcome development. The challenge, however, lies in optimizing competition to achieve the desirable goal of ensuring the dynamic efficiency of the banking sector so that it engenders stability and, consequently, economic growth. Of utmost importance, will be the need to strengthen the various antitrust agencies and ensuring strict adherence to various banking regulations that address issues of competition and including monitoring and developing new ones where necessary. Efforts must also be made to come up with complementary monetary and fiscal policies to sustain and improve on current gains. Regulators and watchdogs must also be alive to their responsibilities.

\section{Reference}

Abdelkader, I. B. \& Mansouri, F. (2013). Competitive Conditions of the Tunisian Banking Industry: An Application of the Panzar- Rosse Model. African development review, 25(4), 526-536. doi:10.1111/1467-8268.12047

Agoraki, M. E. K., Delis, M. D. \& Pasiouras, F. (2011). Regulations, competition and bank risk-taking in $\begin{array}{lllll}\text { transition countries. Journal of Financial Stability, } & \text { 3(1), }\end{array}$ doi:http://dx.doi.org/10.1016/j.jfs.2009.08.002

Aigner, D., Lovell, C. K. \& Schmidt, P. (1977). Formulation and estimation of stochastic frontier production function models. Journal of Econometrics, 6(1), 21-37.

Ajisafe, R. A. \& Akinlo, A. E. (2013). Testing for Competition in the Nigerian Commercial Banking Sector. Modern Economy, 04(07), 501-511. doi:10.4236/me.2013.47054

Akins, B., Li, L., Ng, J. \& Rusticus, T. O. (2016). Bank competition and financial stability: evidence from the financial crisis. Journal of Financial and Quantitative Analysis, 51(01), 1-28.

Amidu, M. (2013). The effects of the structure of banking market and funding strategy on risk and return. $\begin{array}{lllll}\text { International } & \text { Review } & \text { Analysis, } & \text { 28, } & \text { 143-155. }\end{array}$ doi:http://dx.doi.org/10.1016/j.irfa.2013.03.001

Apriadi, I., Sembel, R., Santosa, P. W. \& Firdaus, M. (2016). Banking Fragility in Indonesia: a Panel Vector Autoregression Approach. IJ A B E R, 14(14), 10493-10524. 
Arellano, M. \& Bond, S. (1991). Some tests of specification for panel data: Monte Carlo evidence and an application to employment equations. The Review of Economic Studies, 58(2), 277-297.

Ariss, R. T. (2010). On the implications of market power in banking: Evidence from developing countries. Journal of Banking \& Finance, 34(4), 765-775.

Athanasoglou, P. P., Brissimis, S. N. \& Delis, M. D. (2008). Bank-specific, industry-specific and macroeconomic determinants of bank profitability. Journal of International Financial Markets, Institutions and Money, 18(2), 121-136.

Barro, J. R. \& Barro, R. J. (1990). Pay, performance, and turnover of bank CEOs. National Bureau of Economic Research. Retrieved from doi:10.3386/w3262

Battese, G. E. \& Coelli, T. J. (1992). Frontier production functions, technical efficiency and panel data: with application to paddy farmers in India International Applications of Productivity and Efficiency Analysis (pp. 149-165): Springer.

Battese, G. E. \& Coelli, T. J. (1995). A model for technical inefficiency effects in a stochastic frontier production function for panel data. Empirical economics, 20(2), 325-332.

Bauer, P. W., Berger, A. N., Ferrier, G. D. \& Humphrey, D. B. (1998). Consistency conditions for regulatory analysis of financial institutions: a comparison of frontier efficiency methods. Journal of Economics and Business, 50(2), 85-114.

Beck, T., De Jonghe, O. \& Schepens, G. (2013). Bank competition and stability: Cross-country heterogeneity. Journal of Financial Intermediation, 22(2), 218-244. doi:http://dx.doi.org/10.1016/j.jfi.2012.07.001

Berg, S. A. \& Kim, M. (1994). Oligopolistic interdependence and the structure of production in banking: an empirical evaluation. Journal of Money, Credit and Banking, 4, 309-322.

Berger, A. \& Hannan, T., H. (1998). The efficiency cost of market power in the banking industry: A test of the 'quiet life' and. Review of Economics \& Statistics, 80(3), 454. Retrieved from http://search.ebscohost.com/login.aspx?direct=true\&db=bth\&AN=939292\&site=ehost-live

Berger, A. N., Klapper, L. F. \& Turk-Ariss, R. (2009). Bank competition and financial stability. Journal of Financial Services Research, 35(2), 99-118.

Berger, A. N. \& Mester, L. J. (1997). Inside the black box: What explains differences in the efficiencies of financial institutions? Journal of Banking \& Finance, 21(7), 895-947.

Bolt, W. \& Humphrey, D. (2010). Bank competition efficiency in Europe: A frontier approach. Journal of Banking \& Finance, 34(8), 1808-1817.

Boyd, J. H., De Nicoló, M. G. \& Jalal, A. M. (2009). Bank competition, risk and asset allocations. IMF Working Papers, 9(143). doi:10.5089/9781451872903.001

Campbell, J. Y., Lo, A. W. C. \& MacKinlay, A. C. (1997). The econometrics of financial markets (Vol. 2): princeton University press Princeton, NJ.

Carbó, S., Humphrey, D., Maudos, J. \& Molyneux, P. (2009). Cross-country comparisons of competition and pricing power in European banking. Journal of International Money and Finance, 28(1), 115-134.

Castellanos, S. G., Del Ángel, G. A. \& Garza-García, J. G. (2016). Competition and Efficiency in the Mexican Banking Industry: Theory and Empirical Evidence: Springer.

Casu, B. \& Girardone, C. (2009). Does competition lead to efficiency? The case of EU commercial banks: The Case of EU Commercial Banks SSRN Electronic Journal. doi:10.2139/ssrn.1200362

Casu, B., Girardone, C. \& Molyneux, P. (2012). 3 Is there a conflict between competition and financial stability? Research Handbook on International Banking and Governance, 72. Retrieved from https://books.google.co.za/books?id=Y804tK-

iOnoC\&lpg=PA72\&ots=vYxWMejj5a\&dq=is\%20there\%20a\%20conflict\%20between\%20competition $\% 20$ and\%20financial\%20stability\%3F\&lr\&pg=PA72\#v=onepage\&q=is\%20there\%20a\%20conflict $\% 20$ between $\% 20$ competition $\% 20$ and $\% 20$ financial\%20stability? \&f=false

Casu, B., Girardone, C. \& Molyneux. (2015). Introduction to banking (second ed.). United Kingdom: Pearson Education Limited.

Çelik, T., Kaplan, M. \& Şahin, F. (2015). Efficiency, Concentration and Competition in the Turkish Banking Sector. Iktisat Isletme ve Finans, 30(346), 81-104.

Chiou, W. J. P. \& Porter, R. L. (2015). Does bank capital reduce risk? An application of Stochastic Frontier Analysis and GMM approach. c.-F. Lee, J. Lee (eds), Handbook of Financial Econometrics and Statistics, 246-381.

Chirwa, E. W. (2003). Determinants of commercial banks' profitability in Malawi: a cointegration approach. Applied Financial Economics, 13(8), 565-571. 
Chudik, A. \& Pesaran, M. H. (2013). Large panel data models with cross-sectional dependence: a survey. CAFE Research Paper. SSRN Electronic Journal. doi:10.2139/ssrn.2316333

Chudik, A., Pesaran, M. H. \& Tosetti, E. (2011). Weak and strong cross-section dependence and estimation of large panels. The Econometrics Journal, 14(1), C45-C90.

Čihák, M., Demirgüç-Kunt, A., Pería, M. S. M. \& Mohseni-Cheraghlou, A. (2012). Bank Regulation and Supervision Around the World: A Crisis Update. World Bank Policy Research Working Paper, No. 6286. Retrieved from http://ssrn.com/abstract=2185819

Coelli, T. J. (1996). A guide to FRONTIER version 4.1: a computer program for stochastic frontier production and cost function estimation. Retrieved from ucema.edu.ar

Coelli, T. J., Rao, D. S. P., O'Donnell, C. J. \& Battese, G. E. (2005). An introduction to efficiency and productivity analysis: Springer Science \& Business Media.

de Guevara, J. F. \& Maudos, J. (2011). Banking competition and economic growth: Cross-country evidence. The European Journal of Finance, 17(8), 739-764.

Demirguc-Kunt, A. \& Detragiache, E. (1997). The determinants of banking crises: evidence from industrial and developing countries. Retrieved from https://doi.org/10.1596\%2F1813-9450-1828

Dietsch, M. (1993). Localisation et concurrence dans la banque. Revue economique, 3, 779-790.

Farrell, M. J. (1957). The measurement of productive efficiency. Journal of the Royal Statistical Society. Series A (General), 120(3), 253-290.

Fernandez de Guevara, J., Maudos, J. \& Perez, F. (2005). Market power in European banking sectors. Journal of Financial Services Research, 27(2), 109-137.

Flamini, V., Schumacher, M. L. \& McDonald, M. C. A. (2009). The determinants of commercial bank profitability in Sub-Saharan Africa. IMF Working Papers, 9(15). doi:10.5089/9781451871623.001

Fu, X. M., Lin, Y. R. \& Molyneux, P. (2014). Bank competition and financial stability in Asia Pacific. Journal of Banking \& Finance, 38, 64-77.

Gatev, E., Schuermann, T. \& Strahan, P. E. (2009). Managing bank liquidity risk: How deposit-loan synergies vary with market conditions. Review of Financial Studies, 22(3), 995-1020.

Genetay, N., Lin, Y., Molyneux, P. \& Fu, X. M. (2015). Bank Competition, Efficiency and Liquidity Creation in Asia Pacific: Springer. Retrieved from https://doi.org/10.1057/9781137533845_2

Hamilton, J. D. (1994). Time series analysis (Vol. 2): Princeton university press Princeton.

Hughes, J., Mester, L. \& Moon, C. (2001). Are scale economics in banking elusive or illusive? Evidence obtained by incorporating capital structure and risk into models of bank production. Journal of Banking and Finance, 25. doi:10.2139/ssrn.237812

Hughes, J. P. \& Mester, L. J. (2013). Measuring Performance of Banks: Theory, Practice, Evidence and Some Policy Implications Retrieved from http://ssrn.com/abstract=2306003. Retrieved 3rd September, 2014 http://ssrn.com/abstract=2306003

Hughes, J. P., Lang, W. W., Mester, L. J., Moon, C. G. \& Pagano, M. S. (2003). Do bankers sacrifice value to build empires? Managerial incentives, industry consolidation, and financial performance. Journal of Banking \& Finance, 27(3), 417-447.

Hussain, M. E. \& Hassan, M. K. (2012). Competition, Risk Taking and Efficiency in the US Commercial Banks Prior to 2008 Financial Crisis. Available at SSRN 2003066.

Jondrow, J., Lovell, C. K., Materov, I. S. \& Schmidt, P. (1982). On the estimation of technical inefficiency in the stochastic frontier production function model. Journal of Econometrics, 19(2), 233-238.

Kao, C. \& Liu, S. T. (2009). Stochastic data envelopment analysis in measuring the efficiency of Taiwan commercial banks. European Journal of Operational Research, 196(1), 312-322.

Khan, F., Muneer, S. \& Anuar, M. A. (2013). Relationship between stock prices and economic variables: Sectoral analysis. Actual Problems of Economics, 143, 544-553

Kouki, I. \& Al-Nasser, A. (2014). The implication of banking competition: Evidence from African countries. Research in International Business and Finance. doi:http://dx.doi.org/10.1016/j.ribaf.2014.09.009

Kumbhakar, S. C. \& Lovell, C. K. (2003). Stochastic frontier analysis: Cambridge University Press.

Laeven, L. \& Levine, R. (2009). Bank governance, regulation and risk taking. Journal of Financial Economics, 93(2), 259-275. doi:http://dx.doi.org/10.1016/j.jfineco.2008.09.003

Léon, F. (2015). What do we know about the role of bank competition in Africa Retrieved from http://cerdi.org/production/show/id/1695/type_production_id/1. Retrieved 27 August 2015 http://cerdi.org/production/show/id/1695/type_production_id/1 
Lepetit, L. \& Strobel, F. (2013). Bank insolvency risk and time-varying Z-score measures. Journal of International Financial Markets, Institutions and Money, 25, 73-87.

Liu, H., Molyneux, P. \& Wilson, J. (2013). Competition in banking: measurement and interpretation. Handbook of Research Methods and Applications in Empirical Finance, 197-215. doi: $10.4337 / 9780857936097.00016$

Maghyereh, A. I. \& Awartani, B. (2016). The Influence of Competition on the Financial Stability of Banks in the Gulf Cooperation Council Countries. SSRN Electronic Journal. doi:10.2139/ssrn.2748982

Meeusen, W. \& Van den Broeck, J. (1977). Technical efficiency and dimension of the firm: Some results on the use of frontier production functions. Empirical economics, 2(2), 109-122.

Mileva, E. (2007). Using Arellano-Bond dynamic panel GMM estimators in Stata. Economics Department, Fordham University, 1-10.

Moyo, J., Nandwa, B., Council, D. E., Oduor, J. \& Simpasa, A. (2014). Financial sector reforms, competition and banking system stability in Sub-Saharan Africa. New Perspectives. Retrieved from academia.edu

Mugume, A. (2007). Market structure and performance in Uganda's banking industry. African Econometrics Society. Retrieved from pdfs.semanticscholar.org

Muneer, S., Butt, B. Z. \& Rehman, S. U. (2011). A Multifactor Model of Banking Industry Stock Returns: An Emerging Market Perspective. Information Management and Business Review, 2(6), 267-275

Nguyen, N. B. (2010). Estimation of Technical Efficiency in Stochastic Frontier Analysis. (PhD), Graduate College of Bowling Green State University.

Petersen, M. A. \& Rajan, R. G. (1995). The effect of credit market competition on lending relationships. The Quarterly Journal of Economics, 110(2), 407-443.

Roodman, D. (2006). How to do xtabond2: An introduction to difference and system GMM in Stata. Center for Global Development working paper(103).

Roy, A. D. (1952). Safety First and the Holding of Assets. Econometrica, 20(3), 431-449. doi:10.2307/1907413

Schaeck, K. \& Cihák, M. (2014). Competition, efficiency, and stability in banking. Financial Management, 43(1), 215-241.

Schaeck, K., Cihak, M. \& Simon, W. (2009). Are Competitive Banking Systems More Stable? Journal of Money, Credit and Banking, 41(4), 711-734. doi:10.2307/25483515

Sealey, C. W. \& Lindley, J. T. (1977). Inputs, outputs, and a theory of production and cost at depository financial institutions. The Journal of finance, 32(4), 1251-1266.

Shaffer, S. (2004). Comment on What drives bank competition? Some international evidence by Stijn Claessens and Luc Laeven. Journal of Money, Credit and Banking, 5, 585-592.

Soedarmono, W., Machrouh, F. \& Tarazi, A. (2013). Bank competition, crisis and risk taking: Evidence from emerging markets in Asia. Journal of International Financial Markets, Institutions and Money, 23, 196221.

Suwandi., Kaluge, D. \& Muneer, S. (2016). Crisis Transfer Analysis among Fifteen Major World Stock Markets. Indian Journal of Science and Technology, 9(48), 1-7

Tabak, B. M., Fazio, D. M. \& Cajueiro, D. O. (2012). The relationship between banking market competition and risk-taking: Do size and capitalization matter? Journal of Banking \& Finance, 36(12), 3366-3381.

Uhde, A. \& Heimeshoff, U. (2009). Consolidation in banking and financial stability in Europe: Empirical evidence. Journal of Banking \& Finance, 33(7), 1299-1311.

Valencia, F. \& Laeven, L. (2012). Systemic banking crises database: An update. SSRN Electronic Journal (12163). doi:10.2139/ssrn.2096234

Watkins, K. (2014). Grain, fish money: financing Africa's green and blue revolutions: Africa Progress Report 2014. Retrieved from africabib.org

Williams, J. (2004). Determining management behaviour in European banking. Journal of Banking \& Finance, 28(10), 2427-2460.

Yeyati, E. L. \& Micco, A. (2007). Concentration and foreign penetration in Latin American banking sectors: Impact on competition and risk. Journal of Banking \& Finance, 31(6), 1633-1647. 